\title{
Survival following orbital exenteration at a tertiary brazilian hospital
}

\section{Sobrevida pós exenteração de órbita em hospital de referência}

\author{
Juliana Mika Kato ${ }^{1}$, Fabricio Lopes da Fonseca², Suzana Matayoshi²
}

A B S T R A C T

\begin{abstract}
Objective: to analyze the epidemiology, clinical features and survival rate of patients undergoing orbital exenteration (OE) in a tertiary referral hospital. Methods: we conducted a retrospective study of all patients undergoing OE at the Hospital das Clínicas, FMUSP between January 2007 and December 2012. We collected data records related to gender, age, origin, length of stay, duration of the disease, other treatments related to the disease, number of procedures outside of the face related to the disease, follow-up and histological diagnosis. Results: we treated 37 patients in the study period. The average survival in one year was $70 \%$, in two years, $66.1 \%$, and $58.3 \%$ in three years. There was no significant difference in the one-year survival related to histological diagnosis $(p=0.15)$, days of hospitalization $(p=0.17)$, gender $(p=0.43)$, origin $(p=0.78)$, disease duration $(p=0.27)$ or the number of operations for the tumor $(p=0.31)$. Mortality was higher in elderly patients $(p=0.02)$. The average years of life lost was 33.9 in patients under 60 years, 14.7 in patients in the 61-80 years range and 11.3 in patients over 80 years. Conclusion: the present series of cases is significant in terms of prevalence of orbital exenteration; on the other hand, it shows one of the lowest survival rates in the literature. This suggests an urgent need for improved health care conditions to prevent deforming, radical resections.
\end{abstract}

Key words: Orbital Evisceration. Survival Rate. Carcinoma, Squamous Cell. Carcinoma, Basal Cell.

\section{INTRODUCTION}

$\mathrm{O}$ rbit Exenteration (OE) is one of the most disfiguring procedures among ophthalmologic operations, and is characterized by the complete removal of the contents of the orbital cavity. According to the resection extent, it can be classified into: 1) total, if there is resection of the eyelids; 2) subtotal, when preserving the eyelids; or 3) extensive, when including removal of the bone surrounding walls ${ }^{13}$.

$\mathrm{OE}$ is the therapy of choice when other less radical methods do not result in better prognosis. It is usually indicated in oncologic resections for local control of malignant tumors. However, aggressive diseases or benign tumors that cause uncontrollable pain and structural and/ or extensive lesions also require it. Among the malignant lesions, Basal cell carcinoma (BCC) is the most common skin cancer (80-90\%), followed by squamous cell carcinoma (SCC). Examples of non-malignant diseases include: neurofibromatosis, fibrous dysplasia, mucormycosis, sharply contracted anophthalmic cavity, recurrent meningioma and orbital myiasis ${ }^{4,5}$.

The aesthetic consequences have a strong psychological impact on the patient and require a multidisciplinary approach. Many patients are referred to psychological services after the operation or even refuse to undergo the surgical procedure. Constant vigilance, good doctor-patient relationship, early diagnosis and prompt treatment would provide better prognosis, especially in emerging countries ${ }^{6,7}$.

This retrospective study aims to analyze the epidemiology, clinical features and survival rate of patients undergoing orbital exenteration $(\mathrm{OE})$ in a tertiary referral hospital.

\section{METHODS}

The research project was approved by the of the Hospital das Clínicas, University of São Paulo and we carried out a retrospective study of medical records and pathology reports of all patients who underwent orbital exenteration at the facility between January 2007 and December 2012.

We identified cases by the International Classification of Diseases (ICD-10). We requested the medical records and analyzed them manually. the following data were collected: gender, age, origin, days of hospitalization, time of disease, other operations/treatments performed related to the disease, number of procedures

1. Faculdade de Medicina da Universidade de São Paulo (FMUSP), SP, Brasil; 2. Departamento de Oftalmologia, Universidade de São Paulo, SP, Brasil. 
performed outside the area of the face related to the disease, follow-up, histologic diagnosis and recurrence of lesions. To analyze the survival rate, we contacted the patient's family members by telephone with the help of Social Service for identification and active search for the occurrence of death.

We analyzed the variables by the Kaplan-Meier method, and compared survival curves using the log-rank test, with the R software, version 3.1.1. We calculated the Years of Potential Life Lost (YPLL) by the method proposed by Romeder ${ }^{8}$, adjusted to the life expectancy of Brazilians in $2013^{9}$. The age of reference used was 78.6 for patients under 60 years of age, 83.7 for patients between 61 and 81 years, and 96.7 for patients over 80 .

\section{RESULTS}

We identified 39 patients, of whom two were excluded due to incorrect coding of the disease.

\section{of patients \\ Demographic and clinical characteristics}

The study cohort included 17 men and 20 women, between 0 and 94 years of age (mean 62.2 years). São Paulo, capital, was the origin of 15 patients $(40.5 \%), 13$ $(35.1 \%)$ were from towns in the interior of São Paulo and nine $(24.4 \%)$ from other Brazilian regions. Thirty-three patients were white $(89.2 \%)$, one was black $(2.7 \%)$ and three brown (8.1\%).

The average time of diagnosis was 43.4 months (range three months to 12 years), except for congenital cases. The days of hospitalization ranged from 0 to 62 , average 14. Twelve patients (35.3\%) were not subjected to any other surgical procedure related to the current injury, another 12 (35.3\%) underwent one operation and 10 (29.4\%) underwent more than one. Seventeen patients had additional treatment such as radiotherapy (ten patients $-27 \%$ ), chemotherapy (two patients - 5.4\%) and cryosurgery (three patients $-8.1 \%)$. Most were not submitted to any other operation outside the face area (81.8\%) and eight (21.6\%) were previously treated at least once.

\section{Histopathology}

Histopathological findings included 16 cases of squamous cell carcinoma (43.2\%) and ten of basal cell carcinoma (27.0\%). Other diagnoses included adenoid cystic carcinoma, found in two patients, adenocarcinoma, sebaceous glands, cystic formation, inflammatory process, oncocytic schneiderian papilloma, esthesioneuroblastoma, capillary hemangioma, immature teratoma and malignant melanoma, each found in one patient (Table 1).

\section{Survival Rate}

We excluded congenital cases from the survival analysis. Two patients died during hospitalization.
At the time of the study, 15 patients had died, 15 were alive and six could not be contacted. The average survival rate at one year was $70 \%$ and this figure decreased to $66.1 \%$ and $58.3 \%$ in two and three years, respectively. Mean survival was 47.3 months.

The mortality rate was higher in older patients $(p=0.02)$. There was no significant difference in one-year survival as for the histological diagnosis, if SCC (Figure 1), $B C C$ or non- $E C C /$ non-BCC $(p=0.15)$, days of hospitalization $(p=0.17)$, gender $(p=0.43)$, origin $(p=0.78)$, time of disease progression ( $p=0.27)$ or number of operations related to the tumor ( $p=0.31$ - Table 2$)$.

The average age of death in the age group under 60 was 44.7 years; between 61 and 80 years, 69, and in patients aged over 80 years, 85.4. Considering the life expectancy of Brazil in 2013, the average years of life lost were, respectively, 33.9 years, 14.7 years and 11.3 years. The total YPLL was 191 years (Figure 2).

\section{DISCUSSION}

Orbital exenteration is not a common procedure and is usually done in tertiary referral centers. Our case series presented one of the largest series per year (37 patients in six years). Rahman et al. reported 64 cases in a period of 13 years $^{10}$; Mohr and Esser had 77 in 20 years ${ }^{11}$; Bartley et al. described 102 in 20 years $^{12}$; and Maheshwari et al. published 15 in 10 years ${ }^{13}$.

As the hospital where the study was conducted is a tertiary center, it is expected that $59.9 \%$ of patients originate from other cities as well as from São Paulo. The geographical distance from the origin to the hospital also explains the choice for $\mathrm{OE}$, as the imprecise diagnosis of other health services and lagged time to admission to the

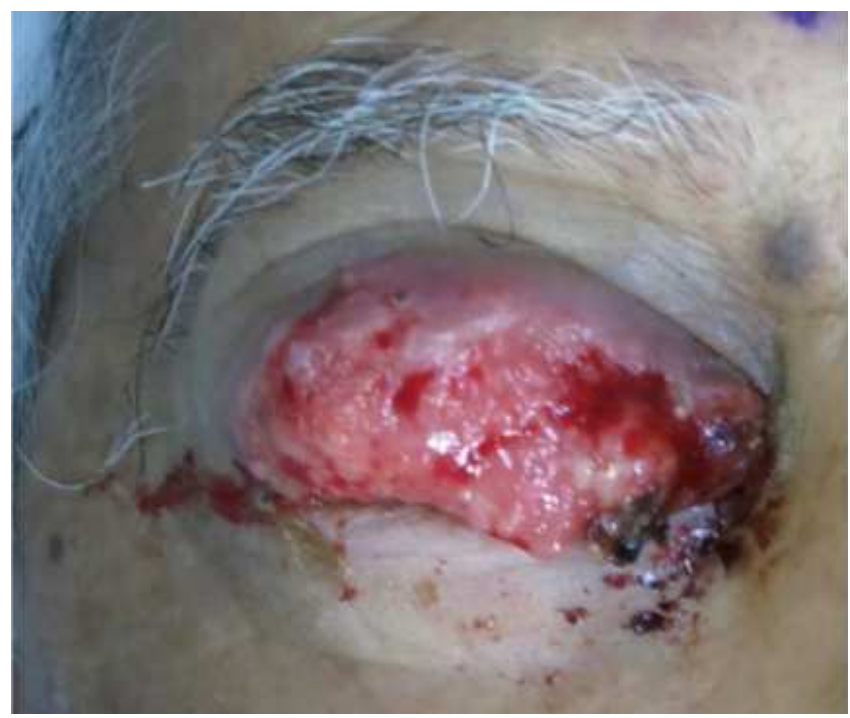

Figure 1 - Example of squamous cell carcinoma with orbital invasion. 
Table 1 - Characteristics of patients undergoing orbital exenteration.

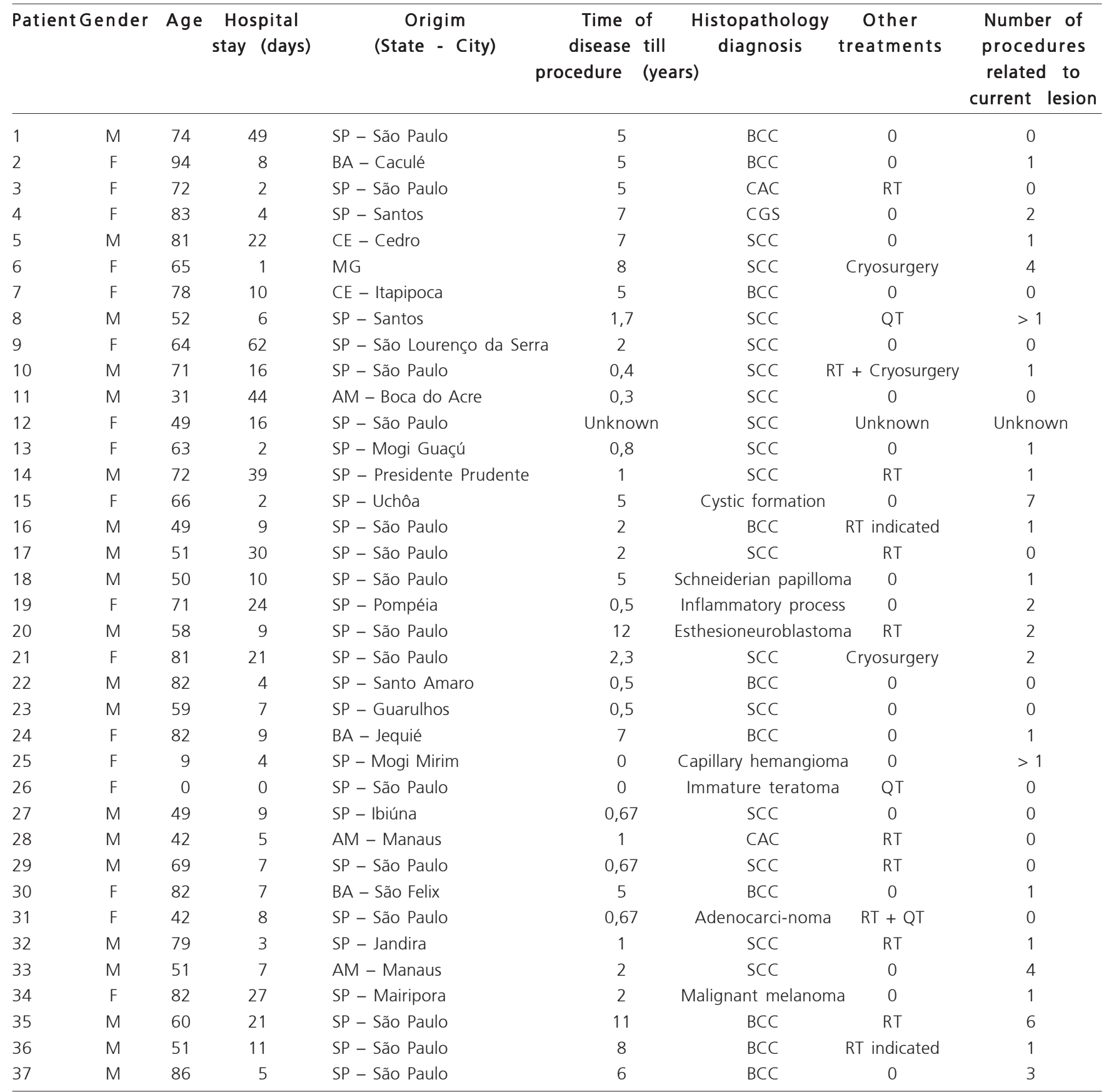

Source: Medical records of the Hospital das Clínicas, Universidade de São Paulo (2007-2012).

BCC: basal cell carcinoma; CAC: cystic adenoid carcinoma; SGC: Sebaceous Glands Carcinoma; SCC: squamous cell carcinoma; RT: radiotherapy; QT: chemotherapy.

tertiary hospital may have made OE the only possible procedure for the control of local disease.

Among the patients cohort, three constituted nonmalignant cases. SCC and BCC together accounted for $70.2 \%$ of the histological diagnosis, which is consistent with other studies. BCC is the most common skin cancer in the periorbital area, but SCC spreads more easily and requires a quick management to prevent disease progression2,10,12,14,15. Our findings are similar to current literature, insofar as BCC represented $27 \%$ of the OE cases, while SCC accounted for $43.2 \%$.

Although SCC is more aggressive than BCC, the difference in survival at one year was not statistically significant between histopathologic diagnoses $(p=0.15)$. The difference was evident only among the first 30 months or so. Some studies, however, had higher mortality after SCC 
Table 2 - Comparison of age, gender, days of hospitalization, origin, time of disease, number of operations and histological diagnosis with survival rate.

\begin{tabular}{|c|c|c|c|c|}
\hline Variable & Number of Cases & Number of Deaths & $\begin{array}{l}\text { Mean Survivala } \\
\text { (months) }\end{array}$ & $\begin{array}{c}\text { One-year } \\
\text { Survival }\end{array}$ \\
\hline \multicolumn{5}{|l|}{ Age range } \\
\hline$<60$ & 11 & 4 & 47.1 & 72.7 \\
\hline $61-80$ & 10 & 3 & 48.4 & 70 \\
\hline$>80$ & 9 & 8 & 23.2 & 66.7 \\
\hline \multicolumn{5}{|l|}{ Gender } \\
\hline $\mathrm{F}$ & 13 & 8 & 41.8 & 61.6 \\
\hline M & 17 & 7 & 52.4 & 76.6 \\
\hline \multicolumn{5}{|l|}{ Hospital stay (days) } \\
\hline$<15$ & 18 & 7 & 54.7 & 83.3 \\
\hline $15-30$ & 8 & 6 & 28.7 & 60 \\
\hline$>30$ & 4 & 2 & 43.8 & 50 \\
\hline \multicolumn{5}{|l|}{ Origin } \\
\hline Other States & 8 & 5 & 37.9 & 76 \\
\hline Capital & 13 & 5 & 46.7 & 69.2 \\
\hline Towns from State interior & 9 & 5 & 39 & 66.7 \\
\hline \multicolumn{5}{|l|}{ Time to diagnosis } \\
\hline$<1$ year & 7 & 5 & 27.1 & 42.9 \\
\hline $1-5$ years & 14 & 6 & 47 & 78.6 \\
\hline$>5$ years & 8 & 3 & 44.9 & 87.5 \\
\hline \multicolumn{5}{|l|}{ Number of procedures } \\
\hline 0 & 11 & 6 & 38.6 & 63.6 \\
\hline 1 & 10 & 6 & 35.3 & 70 \\
\hline$>1$ & 8 & 2 & 56.3 & 87.5 \\
\hline \multicolumn{5}{|l|}{ Histological diagnosis } \\
\hline$B C C$ & 9 & 4 & 46.3 & 88.9 \\
\hline SCC & 13 & 9 & 33.7 & 46.2 \\
\hline Non-BCC / non-SCC & 8 & 2 & 62.8 & 87.5 \\
\hline
\end{tabular}

Source: Medical records of the Hospital das Clínicas, Universidade de São Paulo (2007-2012).

* LogRank Test

BCC: basal cell carcinoma; SCC: squamous cell carcinoma.

than $\mathrm{BCC}^{16-18}$. Additional treatments, such as Mohs micrographic surgery, may have been beneficial in the management of some SCC cases $^{19,20}$.

The average mortality rate after OE also differs from the literature, since our series showed lower survival. Rahman et al. reported a survival rate of $93 \%$ in one year ${ }^{10}$;
Mohr and Esser had 89\% ${ }^{11}$ and Chih-Hung Kuo, 97\% ${ }^{15}$. Karabekmez et al., whose study also come from an emerging country, showed a low survival rate of $50.5 \%{ }^{7}$. Bartley et al. reported a survival rate of $88.6 \%{ }^{12}$.

Younger patients had on average 33.9 years of life lost as a result of diseases that lead to $\mathrm{OE}$, and older

Table 3 - $\quad$ Years of life lost according to age group.

\begin{tabular}{llcccc}
\hline Age Group & N & Interval & $\begin{array}{c}\text { Mean age } \\
\text { at death time }\end{array}$ & $\begin{array}{c}\text { Average years of } \\
\text { life lost }\end{array}$ \\
\hline$<60$ & 4 & $31-51$ & 44.7 & 78.6 & 33.9 \\
$60-80$ & 3 & $64-71$ & 69 & 83.7 & 14.7 \\
$>80$ & 8 & $81-94$ & 85.4 & 96.7 & 11.3 \\
\hline
\end{tabular}

Source: Medical records of the Hospital das Clínicas, Universidade de São Paulo (2007-2012).

YPLL: Years of Potential Life Lost.

* According IBGE (Instituto Brasileiro de Geografia e Estatística), 2013 

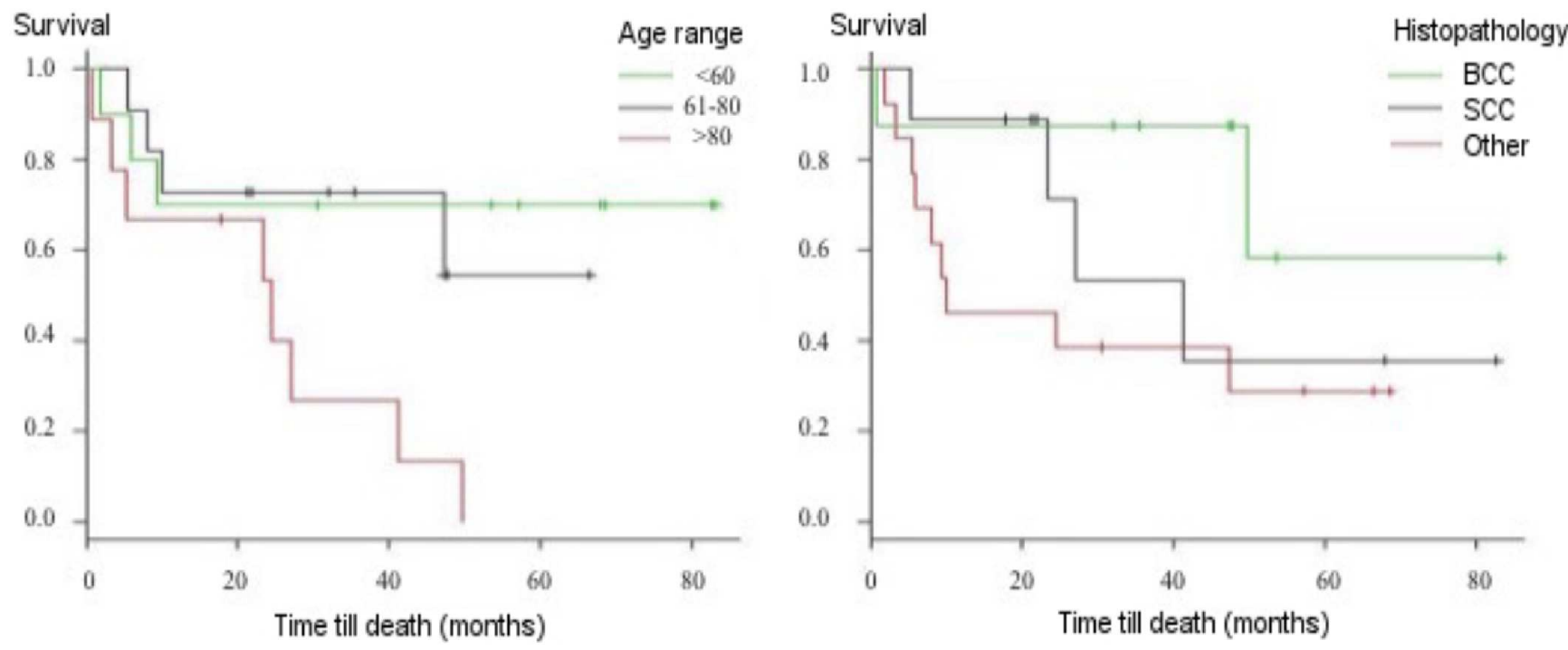

Figure 2 - Comparison of age and histological diagnosis with survival rate.

patients lost more than ten years. Not only the aggressiveness of the disease, but also the lack of information, difficulty in access to health care and delay in correct diagnosis justify the current low survival rate ${ }^{6,21}$. Studies suggest differences in post-SCC mortality between developed and developing countries ${ }^{22}$.

Advanced age may act as a confounding variable because, generally, it is related to comorbidities and other causes of death unrelated to the tumor. However, the predominance of advanced malignant disease is already an indicator of difficulty in access to adequate medical services for immediate treatment, which could improve survival even in the older age group.

In conclusion, this case series is significant in terms of prevalence of Orbit Exenteration; On the other hand, it displayed one of the lowest survival rates in the literature. This suggests an urgent need for improved health care conditions to prevent deforming, radical resections.

\title{
R E S U M O
}

\begin{abstract}
Objetivo: analisar o perfil epidemiológico, as características clínicas e a taxa de sobrevida dos pacientes submetidos à exenteração orbitária (EO) em um hospital de referência terciário. Métodos: estudo retrospectivo de todos os pacientes submetidos à EO no Hospital das Clínicas da FMUSP entre janeiro de 2007 e dezembro de 2012. Foram coletados em prontuários dados referentes ao sexo, idade, procedência, dias de internação, tempo de evolução da doença, outros tratamentos relacionados à doença, número de procedimentos fora da face relacionados à doença, tempo de seguimento e diagnóstico histológico. Resultados: trinta e sete pacientes foram identificados no período de estudo. A sobrevida média em um ano foi $70 \%$, em dois anos, $66,1 \%$ e em três anos $58,3 \%$. Não houve diferença significativa na taxa de sobrevida de um ano em relação ao diagnóstico histológico $(p=0,15)$, dias de hospitalização $(p=0,17)$, sexo $(p=0,43)$, procedência $(p=0,78)$, tempo de evolução da doença $(p=0,27)$ ou número de operações referentes ao tumor $(p=0,31)$. A mortalidade foi maior em pacientes idosos $(p=0,02)$. A média de anos de vida perdidos foi 33,9 em pacientes com menos de 60 anos, 14,7 em pacientes de 61-81 anos e 11,3 em pacientes com mais de 80 anos. Conclusão: a presente série de casos é significativa em termos de prevalência de exenteração orbitária; por outro lado, apresenta uma das menores sobrevidas da literatura. Isso sugere uma necessidade urgente de melhora das condições de assistência médica para a prevenção de ressecções radicais deformadoras.
\end{abstract}

Descritores: Exenteração Orbitária. Taxa de Sobrevida. Carcinoma de Células Escamosas. Carcinoma Basocelular.

\section{REFERENCES}

1. Yeatts RP. The esthetics of orbital exenteration. Am J Ophthalmol. 2005;139(1):152-3.
2. Nassab RS, Thomas SS, Murray D. Orbital exenteration for advanced periorbital skin cancers: 20 years experience. J Plast Reconstr Aesthet Surg. 2007;60(10):1103-9.

3. Frunza A, Slavescu D, Zamfirescu D, Stanciulescu L, Grintescu I, Enache $V$, et al. Orbital exenteration - a salvage procedure? Rom J Morphol Embryol. 2013;54(4):1161-7. 
4. Roche $P$, Timon $C$. Orbital exenteration in periorbital malignancies. Surgeon. 2012;10(4):189-93.

5. Qassemyar A, Aljudaibi N, Wavreille O, Mortier L, MartinotDuquennoy V, Guerreschi P. Orbital exenteration and periorbital skin cancers. J Oral Maxillofac Surg. 2014;72(4):811-6.

6. Leme VR, Oliveira MVD, Boeira Juinior N, Cruz AAV. Causas de exenteração. Arq Bras Oftalmol. 1999;62(1):75-7.

7. Karabekmez FE, Selimoglu MN, Duymaz A, Karamese MS, Keskin M, Savaci N. Management of neglected periorbital squamous cell carcinoma requiring orbital exenteration. J Craniofac Surg. 2014;25(3):729-34.

8. Romeder JM, McWhinnie JR. Potential years of life lost between ages 1 and 70: an indicator of premature mortality for health planning. Int J Epidemiol. 1977;6(2):143-51.

9. Instituto Brasileiro de Geografia e Estatística [homepage na Internet]. Tábuas completas de mortalidade [acessado em: jun 14]. Disponível em: http://www.ibge.gov.br/home/estatistica/ populacao/tabuadevida/2013/default.shtm

10. Rahman I, Cook AE, Leatherbarrow B. Orbital exenteration: a 13 year Manchester experience. Br J Ophthalmol. 2005;89(10):133540

11. Mohr C, Esser J. Orbital exenteration: surgical and reconstructive strategies. Graefes Arch Clin Exp Ophthalmol. 1997;235(5):28895.

12. Bartley GB, Garrity JA, Waller RR, Henderson JW, Ilstrup DM. Orbital exenteration at the Mayo Clinic. 1967-1986. Ophthalmology. 1989;96(4):468-73.

13. Maheshwari R. Review of orbital exenteration from an eye care centre in Western India. Orbit. 2010;29(1):35-8.

14. Sirianni $D$, Leles $C R$, Mendonça EF. A 12-year retrospective survey of management of patients with malignant neoplasms in the orbital cavity in a brazilian cancer hospital. Open Dent J. 2013;7:140-5.
15. Kuo CH, Gao K, Clifford A, Shannon K, Clark J. Orbital exenterations: an 18-year experience from a single head and neck unit. ANZ J Surg. 2011;81(5):326-30.

16. Rees JR, Zens MS, Celaya MO, Riddle BL, Karagas MR, Peacock JL. Survival after squamous cell and basal cell carcinoma of the skin: A retrospective cohort analysis. Int J Cancer. 2015;137(4):878-84.

17. Jensen $A O$, Bautz $A$, Olesen $A B$, Karagas $M R$, Sorensen $H T$, Friis $S$. Mortality in Danish patients with nonmelanoma skin cancer, 19782001. Br J Dermatol. 2008;159(2):419-25.

18. Johannesdottir $S A$, Lash $T L$, Jensen $A O$, Farkas $D K$, Olesen $A B$. Mortality in cancer patients with a history of cutaneous squamous cell carcinoma-a nationwide population-based cohort study. BMC Cancer. 2012;12:126

19. Harvey DT, Taylor RS, Itani KM, Loewinger RJ. Mohs micrographic surgery of the eyelid: an overview of anatomy, pathophysiology, and reconstruction options. Dermatol Surg. 2013;39(5):673-97.

20. Spencer JM, Nossa R, Tse DT, Sequeira M. Sebaceous carcinoma of the eyelid treated with Mohs micrographic surgery. J Am Acad Dermatol. 2001;44(6):1004-9.

21. Schayan-Araghi K, Press UP, Hübner H. Orbital exenteration. A preventable course in tumor treatment?! Ophthalmologe. 1994;91(4):536-9.

22. Boyers LN, Karimkhani C, Naghavi M, Sherwood D, Margolis DJ, Hay RJ, et al. Global mortality from conditions with skin manifestations. J Am Acad Dermatol. 2014;71(6):1137-43.e.17.

Received in: 10/10/2015

Accepted for publication: 16/12/2015

Conflict of interest: none.

Source of funding: none.

Mailing address:

Juliana Mika Kato

E-mail: mika.kto@gmail.com 